Article

\title{
Comparative Plastomics of Ashwagandha (Withania, Solanaceae) and Identification of Mutational Hotspots for Barcoding Medicinal Plants
}

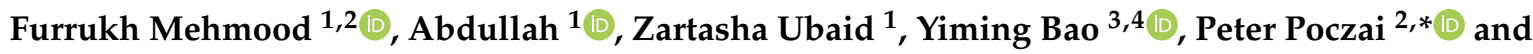 \\ Bushra Mirza $1,5, *$ (D) \\ 1 Department of Biochemistry, Quaid-i-Azam University, Islamabad 45320, Pakistan; \\ mfarrukh@bs.qau.edu.pk (F.M.); abd.ullah@bs.qau.edu.pk (A.); zartashaubaid.zu@gmail.com (Z.U.) \\ 2 Botany Unit, Finnish Museum of Natural History, University of Helsinki, P.O. Box 7, \\ FI-00014 Helsinki, Finland \\ 3 National Genomics Data Center, Beijing Institute of Genomics, Chinese Academy of Sciences, and China \\ National Center for Bioinformation, Beijing 100101, China; baoym@big.ac.cn \\ 4 School of Future Technology, University of Chinese Academy of Sciences, Beijing 100049, China \\ 5 Vice Chancellor of Lahore College for Women University, Lahore 54000, Pakistan \\ * Correspondence: peter.poczai@helsinki.fi (P.P.); bushramirza@qau.edu.pk (B.M.)
}

Received: 9 May 2020; Accepted: 12 June 2020; Published: 15 June 2020

\begin{abstract}
Within the family Solanaceae, Withania is a small genus belonging to the Solanoideae subfamily. Here, we report the de novo assembled chloroplast genome sequences of $W$. coagulans, W. adpressa, and W. riebeckii. The length of these genomes ranged from 154,162 to 154,364 base pairs (bp). These genomes contained a pair of inverted repeats (IRa and IRb) ranging from 25,029 to $25,071 \mathrm{bp}$ that were separated by a large single-copy (LSC) region of 85,635-85,765 bp and a small single-copy (SSC) region of 18,457-18,469 bp. We analyzed the structural organization, gene content and order, guanine-cytosine content, codon usage, RNA-editing sites, microsatellites, oligonucleotide and tandem repeats, and substitutions of Withania plastomes, which revealed high similarities among the species. Comparative analysis among the Withania species also highlighted 10 divergent hotspots that could potentially be used for molecular marker development, phylogenetic analysis, and species identification. Furthermore, our analyses showed that even three mutational hotspots (rps4-trnT, $\operatorname{trn} \mathrm{M}-a t p \mathrm{E}$, and $r p s 15)$ were sufficient to discriminate the Withania species included in current study.
\end{abstract}

Keywords: ashwagandha; chloroplast genome; indels; medicinal plants; mutational hotspots; phylogenomics; Solanaceae; substitutions; Withania

\section{Introduction}

The globally distributed megadiverse Solanaceae family includes 93 genera and 2700 species [1-3]. The genus Withania Pauq., belonging to the subfamily Solanoideae, contains 10-20 species [1]. Among the worldwide list of Withania species, ashwagandha or winter cherry (W. somnifera (L.) Dunal) and paneer booti or ashutosh booti (W. coagulans (Stocks) Dunal) are considered highly important due to their therapeutic potential. Withania species are pivotal in the Ayurvedic medicine system in Southeast Asia, and W. somnifera has been used for medicinal purposes for around 3000 years [4,5]. Many studies of Withania have described various pharmacological properties of these species, (e.g., anti-inflammatory, anticancer, antidepressant, neuroprotective, and hepatoprotective) [6-9]. The ubiquity of such herbal products has expanded globally in recent decades. The worldwide market for medicinal plants is anticipated to reach 5 trillion USD by 2050, with Europe driving the market [10]. Although medicinal plants are outstanding sources of innovative drug development, assessing their pharmacological 
properties and effectiveness requires comprehensive approaches. Ashwagandha (Withania species) products show irregularities in quality through the herbal medicinal value chain affecting their impact and safety [11]. The quality of these manufactured herbal products is globally highly variable, and consistent analytical approaches are required to identify and monitor their quality along the value chain. The herbal medicine industry has considered DNA barcoding as a method that can be consistently applied in quality control over the manufactured products and to identify medicinal materials to protect consumers from dishonest suppliers. In addition, this method can also be used to identify toxic herbal materials in life-threatening situations, prevent poisoning, and improve control procedures of herbal drug substances [12].

The structure and composition of the chloroplast genome (or plastome) can be utilized to generate molecular markers that can be used in DNA barcoding [13]. Chloroplasts are important and universal organelles that are essential for photosynthesis. Chloroplasts are also associated with the synthesis of vitamins, pigments, fatty acids, and amino acids through various biochemical pathways [14]. Among many plant species, plastomes are 75-250 kilobases $(\mathrm{kb})$ in size [15] and contain 120 genes, which include protein-encoding, ribosomal RNA (rRNA), and transfer RNA (tRNA) genes [16]. The structure of angiosperm plastomes varies from circular to linear even within the cells of the same individual [17]. Circular-formed plastomes show a typically quadripartite in structure, with two inverted repeats (IRs) separating the large single-copy (LSC) and a small single-copy (SSC) regions $[15,18,19]$. Plastomes show frequent variation in the number of tandem repeats, insertions and deletions (indels), single nucleotide polymorphism (SNPs), and as well as other rearrangements including translocations and inversion [19-21]. Plastomes have been termed as "super barcodes", due to their comparatively conserved organization, gene content, adequate level of nucleotide substitution in protein-encoding genes, and uniparental inheritance, which make them excellent sources of phylogenetic reconstruction and species identification at diverse taxonomic levels [22-25]. Plastome-sequencing data can also be useful for agricultural trait improvement [26], transplastomics [27,28], population genetics [29], and conservation of species facing extinction [30].

Here, we aimed to assemble and compare the complete chloroplast genome sequences of W. coagulans, W. adpressa Coss., and W. riebeckii Schweinf. ex Balf.f. in addition to the previously reported W. somnifera genome [24]. We also sought to analyze the phylogenetic relationship of the genus among the Solanaceae family and to analyze differences in the organization of Withania plastomes such as repeats, indels, and substitutions, and to identify mutational hotspots for future DNA barcoding.

\section{Materials and Methods}

\subsection{Genome Assembly and Annotation}

Fresh green leaves of W. coagulans were obtained from Mianwali, Pakistan $\left(32.5839^{\circ}\right.$ N $71.5370^{\circ}$ E). The leaf segments were washed in 70\% ethanol and total genomic DNA extraction was carried out according to the CTAB (cetyltrimethylammonium bromide) method of Lu et al. [31]. DNA quality and concentration were assessed by Colibri spectrometer Nanodrop (Titertek-Berthold, Berthold Detection Systems $\mathrm{GmbH}$, Pforzheim, Germany) and 1\% agarose gel electrophoresis. Genome sequencing was carried out by the Beijing Institute of Genomics using the Illumina HiSeq PE150 platform (Illumina Inc., San Diego, CA, USA). Furthermore, the Illumina sequence data of W. adpressa (5 Gb) and W. riebeckii $(5 \mathrm{~Gb})$ were acquired from the sequence read archive (SRA) deposited under accession numbers SRR8718119 and SRR8718120. The raw sequencing read quality was verified with the FastQC tool [32]. We used Velvet 1.2.10 [33] with k-mer sizes of 31, 41, 51, and 71 to initially assemble the large sequence contigs from raw paired-end reads. These contigs were then combined to produce complete chloroplast genomes though de novo assembly carried out with Geneious R8.1 (Biomatters Ltd., Auckland, New Zealand) [34]. The junction sites between LSC, SSC, and IR were determined for these novel assembled plastomes. Annotations of these genomes were performed, using GeSeq [35] and CPGAVAS2 [36]. The results were compared, inspected checking the start/stop codons manually. 
Additionally, tRNA genes were identified using tRNAscan-SE version 2.0 under default parameters [37] and ARAGORN version 1.2.38 [38]. CPGAVAS2 [36] and Clico FS [39] were used to draw circular maps of the genomes. The average coverage depths of the Withania species plastomes were determined by mapping the reads to the de novo assembled plastome through the Burrows-Wheeler aligner (BWA) [40] and visualizing in the Tablet [41]. The novel annotated plastomes were deposited in NCBI under the following accession numbers: W. coagulans (MN216390), W. adpressa (BK010847), and W. riebeckii (BK010849). The plastome of W. coagulans was also deposited in the GWH database of the National Genomics Data Center [42] (accession number GWHACBF00000000).

\subsection{Comparative Chloroplast Genome Analysis}

All de novo chloroplast genomes were aligned with multiple alignment using fast Fourier transform (MAFFT) 7.309 [43], using default parameters. Protein-encoding genes, intergenic spacer (IGS) regions, and introns were extracted to calculate the average number of nucleotide differences per site or nucleotide diversity $(\pi)$ with a $100 \mathrm{bp}$ window size as implemented in DnaSP v6 [44]. The substitution, transition (Ts), and transversion (Tv) rates were resolved from the MAFFT alignment, using W. somnifera as a reference. Each structural element, including the LSC, SSC, and IR, was aligned individually to analyze SNPs and indel polymorphisms with Geneious and DnaSP, respectively. The junction sites of the IRs and their border positions were compared using all Withania species and six additional Solanaceae outgroup species (Table S9), using the default setting of the IRscope [45]. The intergeneric comparison was carried out to gain insight to differences and syntenies that may exist between Withania and other Solanaceae species. Circoletto [46] was used to compare structural features of Withania chloroplast genomes using blastn search (e-value of $<1 \times 10^{-10}$ ) to create a Circos output.

The predictive RNA editor for plants-chloroplast genes (PREP-cp) was used to predict putative RNA editing sites using default settings [47], while codon usage and amino-acid frequencies were analyzed in Geneious R8.1. The ratios of synonymous (Ks) and non-synonymous (Ka) substitutions for each extracted protein-encoding gene were calculated with DnaSP for all Withania, using W. somnifera as reference. The data were interpreted as: $\mathrm{Ka} / \mathrm{Ks}>1, \mathrm{Ka} / \mathrm{Ks}=1, \mathrm{Ka} / \mathrm{Ks}<1$, representing positive, neutral, and purifying selection, respectively. Microsatellites in Withania plastomes were detected with the microsatellite-web (MISA) [48], using a minimal repeat number of 7 for mononucleotide simple sequence repeats (SSRs), 4 for dinucleotide SSRs, and 3 for tri-, tetra-, penta-, and hexanucleotide SSRs. REPuter [49] was also used to locate forward (F), reverse (R), palindromic (P), and complementary (C) repeats with the following parameters: min. repeat size $30 \mathrm{bp}$, Hamming distance 3 , min. similarity percentage of two repeat copies $90 \%$, and max. computed repeats 500 . A subsequent search for repeats was also carried out with tandem repeat finder [50] using default parameters.

\subsection{Phylogenomic Analysis}

We included all available Withania plastome sequences in our analysis and added further Solanaceae plastomes (Organelle Genome Resources of NCBI, accessed on 21 January 2020) from closely related groups of Physaleae and additional taxonomic groups from the so-called ' $x=12$ clade'. This group encompasses species of the traditional subfamily Solanoideae, Nicotiana L. and the Australian endemic tribe Anthocercideae belonging to Nicotianoideae. This strongly supported group is united with the cytological synapomorphy of chromosome numbers based on 12 pairs [1]. We used Petunia $\times$ atkinsiana (Sweet) D. Don ex W.H. Baxter (Syn.: Petunia $\times$ hybrida Vilm.) as an outgroup to root our tree, since this was the only available complete chloroplast genome sequence outside the $x=12$ clade. For phylogenetic analysis, we removed one of the IR regions (IRa), and subsequently excised all protein-encoding genes from the plastomes. The reading frames were manually verified during extraction by checking the start and stop codons. We discarded $\operatorname{accD} \mathrm{D}, y c f 1$, and $y c f 15$ from our final alignment, because these genes were highly variable in size. The trans-spliced rps 12 was also not included in the phylogenetic alignment together with sequence of the inf A pseudogene. The nucleotide sequences of 74 protein-coding genes were aligned with MAFFT (default setting) via the Geneious shell. 
IQ-TREE [51] was used to determine the best-fitting models for each partition of concatenated matrix using the TESTMERGEONLY and AICc (Akaike information criterion corrected for small sample sizes) options in the built-in ModelFinder [52]. The maximum likelihood (ML) tree search was carried out using the ultrafast bootstrap approximation (UFBoot; [53]) with 1000 replicates. UFBoot reduces computing time and provides an efficient alternative to standard bootstrap [53]. Branch supports were also assessed using the SH-like approximate likelihood ratio test (SH-aLRT), while final phylogenetic trees were edited using TreeDyn [54,55].

For further analyses we divided the dataset into protein-coding gene subsets according to the heuristic searches carried out with Partition Finder v1.1.1 [56] and default settings using Bayesian information criterion (BIC). Intron regions were regarded as distinct subsets. Partitioned Bayesian phylogenetic analyses were carried out with MrBayes v.3.2.3 [57]. jModelTest [58] was used with default settings to infer fitting substitution models (see Table S10). One cold and three heated Markov chains were run parallel with $2 \times 10^{6}$ generations sampling every 100 th tree per generation, with unlinked parameters across partitions. Branch length and topology parameters were set unlinked. Convergence was checked using the average standard deviation of split frequencies (ASDFs; <0.01) was used to measure convergence of the runs. A majority-rule consensus tree was constructed from the runs with a $25 \%$ burn-in removal.

\section{Results}

\subsection{Organization and Characteristics of Withania Plastomes}

Our comparative analysis revealed that Withania species have similar plastome structures (Figure 1 and Table 1). The length of the assembled plastome varied between 154,162 and 154,364 bp. The average coverage depth of the assembled plastomes of W. coagulans, W. adpressa, and W. riebeckii was 573×, $566 \times$, and 590×, respectively. The total guanosine-cytosine (GC) content of the de novo assembled Withania plastomes was $37.7 \%$, as was the previously sequenced species.

The IRs showed a higher GC content (43.2\%) compared to the large- (35.7\%) and small-single copy regions (31.8\%), which could have been due to the occurrence of rRNA genes containing GC-rich regions [19,59-61]. The plastomes of the de novo assembled Withania species had 132 genes from which 18 were represented in duplication in the inverted repeats (Table 2, Figure 2). All Withania plastomes contained 86 protein-encoding, 37 tRNA, and 8 rRNA genes. The IR regions contained 18 duplicated genes and out of these 7 were protein-encoding, 4 were rRNA, and 7 were tRNA genes. The $c l p \mathrm{P}$ and $y c f 3$ genes had two introns in their nucleotide sequence, while $r p s 16, \operatorname{at} p \mathrm{~F}, r p o \mathrm{C} 1, \operatorname{pet} \mathrm{B}$, pet $\mathrm{D}, r p l 16, n d h \mathrm{~A}, r p l 2$, and $n d h \mathrm{~B}$ had only one. The $5^{\prime}$ end exon of the trans-spliced gene rps12 was found in the LSC and the $3^{\prime}$ end exons were located in the IR. The GC content was the highest among tRNAs (53\%) and rRNAs (55.3\%). Hydrophobic amino acids were abundant, while the acidic amino acids were present in the least amount in plastomes of the genus Withania. These amino acids were adenine-thymine (AT)-rich sequences in all species (Figure 3A). The analysis of codon usage and amino acids frequencies indicated leucine (Leu) as the most frequent and cysteine (Cys) as a rare amino acid in Withania plastomes (Figure 3B). The codon usage also revealed a shift towards A/T at the third codon position (Table S1). 


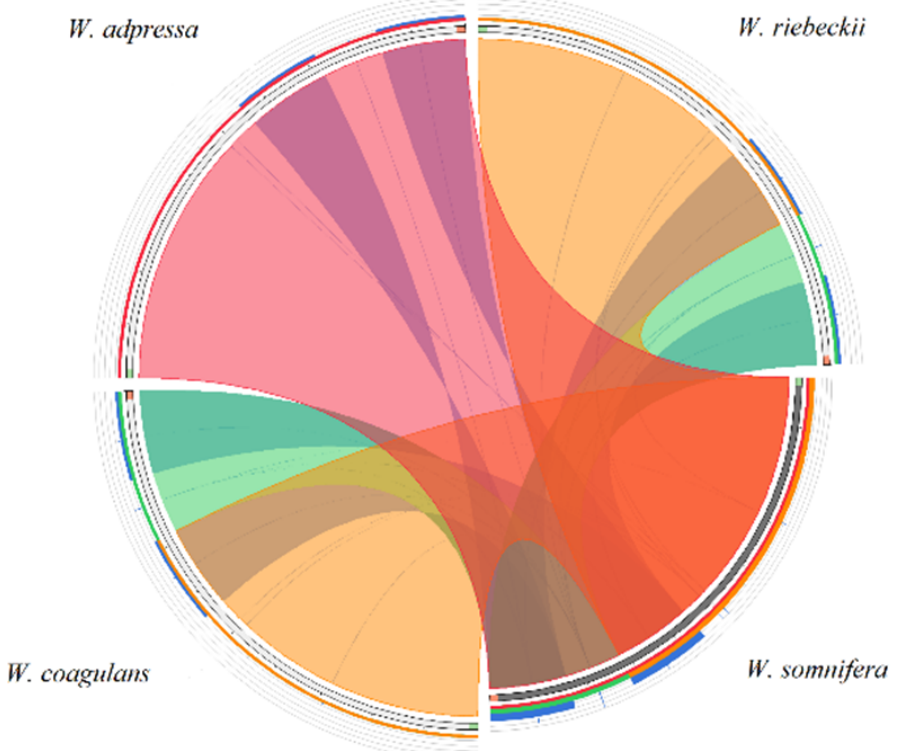

Figure 1. Structural comparison of Withania plastomes showing a high level of synteny and the lack of large rearrangements. The start and end points of the sequences are marked by green and orange blocks. The colored blocks outside the sequences refer to the score/max bit core ration, with green $\leq 0.50$, orange $\leq 0.75$, and red $>0.75$. Blue blocks and chords represent the inverted repeats (IRs).

Table 1. Summary of Withania chloroplast genome features.

\begin{tabular}{|c|c|c|c|c|c|}
\hline \multicolumn{2}{|c|}{ Characteristics } & W. somnifera & W. coagulans & W. adpressa & W. riebeckii \\
\hline \multicolumn{2}{|c|}{ Size (base pair; bp) } & 154,386 & 154,196 & 154,364 & 154,162 \\
\hline \multicolumn{2}{|c|}{ LSC length (bp) } & 85,688 & 85,659 & 85,765 & 85,635 \\
\hline \multicolumn{2}{|c|}{ SSC length (bp) } & 18,464 & 18,467 & 18,457 & 18,469 \\
\hline \multicolumn{2}{|c|}{ IR length (bp) } & 25,117 & 25,035 & 25,071 & 25,029 \\
\hline \multicolumn{2}{|c|}{ Number of genes } & 132 & 132 & 132 & 132 \\
\hline \multicolumn{2}{|c|}{ Protein-coding genes } & 86 & 86 & 86 & 86 \\
\hline \multicolumn{2}{|c|}{ tRNA genes } & 37 & 37 & 37 & 37 \\
\hline \multicolumn{2}{|c|}{ rRNA genes } & 8 & 8 & 8 & 8 \\
\hline \multicolumn{2}{|c|}{ Duplicate genes } & 18 & 18 & 18 & 18 \\
\hline \multirow{8}{*}{ GC content } & Total (\%) & $37.7 \%$ & $37.7 \%$ & $37.7 \%$ & $37.7 \%$ \\
\hline & LSC (\%) & $35.7 \%$ & $35.7 \%$ & $35.7 \%$ & $35.7 \%$ \\
\hline & SSC (\%) & $31.8 \%$ & $31.8 \%$ & $31.8 \%$ & $31.8 \%$ \\
\hline & IR (\%) & $43.2 \%$ & $43.2 \%$ & $43.2 \%$ & $43.2 \%$ \\
\hline & CDS (\%) & $38.2 \%$ & $38.2 \%$ & $38.2 \%$ & $38.2 \%$ \\
\hline & rRNA (\%) & $55.3 \%$ & $55.3 \%$ & $55.3 \%$ & $55.3 \%$ \\
\hline & tRNA $(\%)$ & $53 \%$ & $52.9 \%$ & $53 \%$ & $53 \%$ \\
\hline & All gene (\%) & $40 \%$ & $39.8 \%$ & $39.8 \%$ & $39.8 \%$ \\
\hline \multicolumn{2}{|c|}{ Protein coding part (CDS) (\%bp) } & $50.9 \%$ & $51.0 \%$ & $51.0 \%$ & $51.0 \%$ \\
\hline \multicolumn{2}{|c|}{ All gene $(\% b p)$} & $72.06 \%$ & $72.11 \%$ & $72.07 \%$ & $72.13 \%$ \\
\hline \multicolumn{2}{|c|}{ Non-coding region (\%bp) } & $27.94 \%$ & $27.89 \%$ & $27.93 \%$ & $27.87 \%$ \\
\hline
\end{tabular}




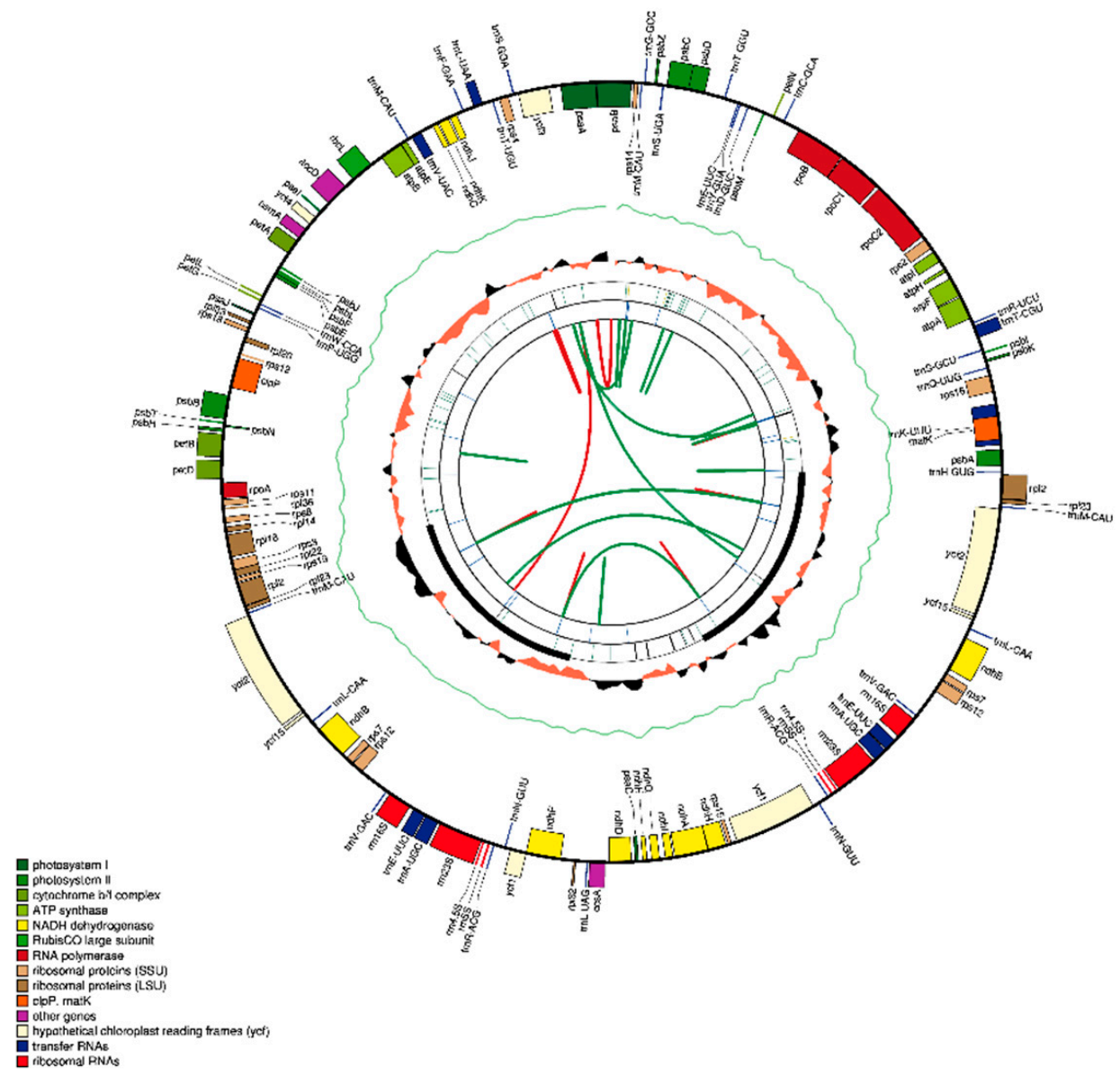

Figure 2. Consensus circular genome map of Withania plastomes. The first larger ring represents the gene structure of the chloroplast genome. The GC content is plotted as a green line while a skewed GC plot is presented as an orange/black track around the inner circles. The second ring is displaying the IRs as longer black boxes, while tandem repeats are represented by short bars. The third, and last circle shows the output of MISA microsatellite detection, where reverse repeats are connected with green arcs, while red arcs represent forward repeats.
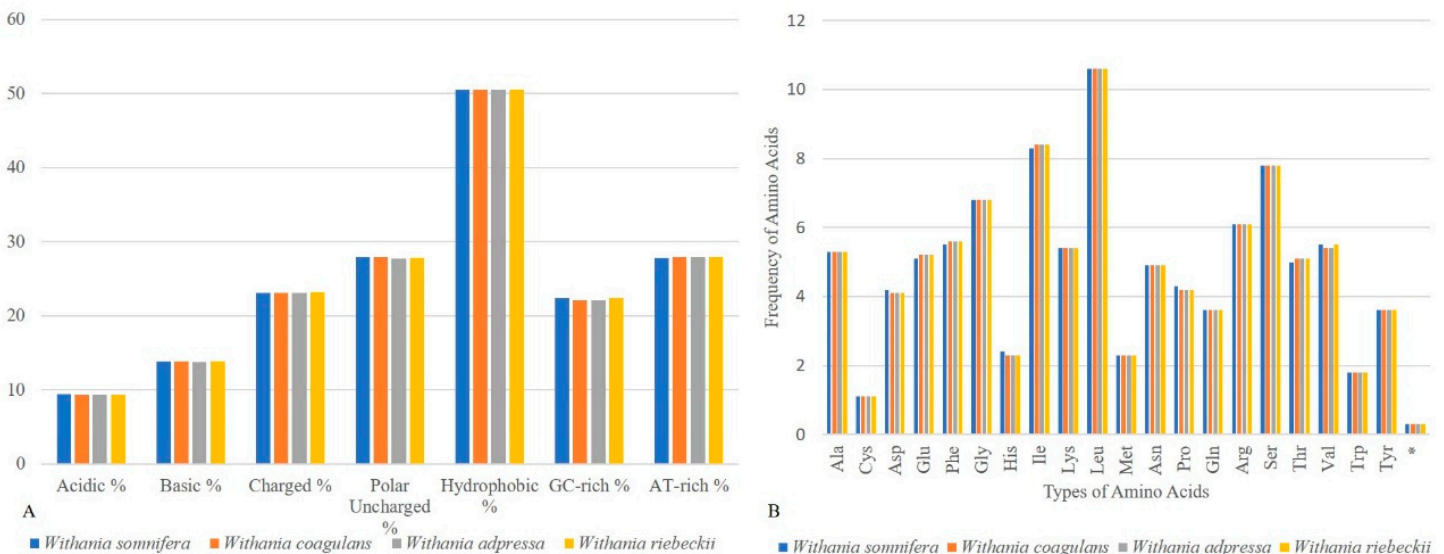

Figure 3. (A) Assessment of amino-acid groups and (B) amino-acid frequency comparison among Withania species. 
Table 2. Genes and their functional categories in Withania chloroplast genomes.

\begin{tabular}{|c|c|c|c|c|c|c|}
\hline Category for Gene & Group of Gene & & & Jame of Gene & & \\
\hline \multirow{13}{*}{$\begin{array}{l}\text { Photosynthesis-Related } \\
\text { Genes }\end{array}$} & Photosystem I & $p s a \mathrm{~A}$ & $p s a \mathrm{~B}$ & $p s a \mathrm{C}$ & $p s a \mathrm{I}$ & $p s a \mathrm{~J}$ \\
\hline & \multirow{3}{*}{ Photosystem II } & $p s b \mathrm{~A}$ & $P s b \mathrm{~B}$ & $p s b C$ & $p s b \mathrm{D}$ & $p s b \mathrm{E}$ \\
\hline & & $p s b \mathrm{~F}$ & $p s b \mathrm{H}$ & $p s b \mathrm{I}$ & $p s b \mathrm{~J}$ & $p s b \mathrm{~K}$ \\
\hline & & $p s b \mathrm{~L}$ & $p s b \mathrm{M}$ & $p s b \mathrm{~N}$ & & \\
\hline & \multirow{2}{*}{$\begin{array}{l}\text { Cytochrome } \\
\text { b/f complex }\end{array}$} & $p s b \mathrm{~T}$ & $p s b Z$ & $\operatorname{pet} \mathrm{N}$ & petA & pet $\mathrm{L}$ \\
\hline & & petG & pet $\mathrm{D}^{*}$ & petB * & & \\
\hline & \multirow{2}{*}{ ATP synthase } & $\operatorname{atpI}$ & $\operatorname{atpH}$ & $\operatorname{atp} \mathrm{A}$ & $\operatorname{atp} \mathrm{F}^{*}$ & atp $\mathrm{E}$ \\
\hline & & $\operatorname{atp} \mathrm{B}$ & & & & \\
\hline & $\begin{array}{l}\text { Assembly/stability } \\
\text { of photosystem I }\end{array}$ & $y c f 3^{* *}$ & $y c f 4$ & & & \\
\hline & \multirow{3}{*}{$\begin{array}{c}\text { NADPH } \\
\text { dehydrogenase }\end{array}$} & $n d h \mathrm{~B}^{*, \mathrm{a}}$ & $n d h \mathrm{H}$ & $n d h \mathrm{~A}^{*}$ & $n d h \mathrm{I}$ & $n d h \mathrm{G}$ \\
\hline & & $n d h \mathrm{~J}$ & $n d h \mathrm{E}$ & $n d h \mathrm{~F}$ & $n d h \mathrm{C}$ & $n d h \mathrm{~K}$ \\
\hline & & $n d h \mathrm{D}$ & & & & \\
\hline & Rubisco & $r b c \mathrm{~L}$ & & & & \\
\hline \multirow{14}{*}{$\begin{array}{l}\text { Transcription } \\
\text { and Translation } \\
\text { Related Genes } \\
\text { RNA Genes }\end{array}$} & \multirow{4}{*}{$\begin{array}{c}\text { Transcription } \\
\text { Small subunit } \\
\text { of ribosome }\end{array}$} & rpoA & rpoc2 & $r p o \mathrm{C} 1 *$ & rpo B & $r p s 16^{*}$ \\
\hline & & $r p s 7^{\text {a }}$ & $r p s 15$ & $r p s 19$ & $r p s 3$ & $r p s 8$ \\
\hline & & $r p s 14$ & $r p s 11$ & $r p s 12^{\mathrm{a}, *}$ & $r p s 18$ & $r p s 4$ \\
\hline & & $r p s 2$ & & & & \\
\hline & \multirow{2}{*}{$\begin{array}{l}\text { Large subunit } \\
\text { of ribosome }\end{array}$} & $r p l 2^{\mathrm{a}, *}$ & $r p l 23^{\mathrm{a}}$ & $r p l 32$ & $r p l 22$ & rpl14 \\
\hline & & rpl33 & rpl36 & $r p l 20$ & $r p l 16^{*}$ & \\
\hline & Ribosomal RNA & $r r n 16^{\mathrm{a}}$ & $r r n 4.5^{\text {a }}$ & $r r n 5^{\text {a }}$ & $r r n 23^{a}$ & \\
\hline & \multirow{7}{*}{ Transfer RNA } & $\operatorname{trnV-GAC}{ }^{\mathrm{a}}$ & $\operatorname{trnI-CAU} *$ & $\operatorname{trn} \mathrm{A}-\mathrm{UGC} \mathrm{a}, *$ & $\operatorname{trn} \mathrm{N}-\mathrm{GUU}^{\mathrm{a}}$ & trnP-UGG \\
\hline & & trnW-CCA & $\operatorname{trn} \mathrm{V}-\mathrm{UAC}{ }^{*}$ & $\operatorname{trn} \mathrm{L}-\mathrm{UAA} *$ & $\operatorname{trn} \mathrm{F}-\mathrm{GAA}$ & $\operatorname{trnR} \mathrm{ACG}^{\mathrm{a}}$ \\
\hline & & $\operatorname{trnT-UGU}$ & $\operatorname{trn} \mathrm{G}-\mathrm{UCC}{ }^{\mathrm{a}, *}$ & trnT-GGU & $\operatorname{trn} \mathrm{R}-\mathrm{UCU}$ & $\operatorname{trn} \mathrm{E}-\mathrm{UUC}$ \\
\hline & & trnY-GUA & trnD-GUC & $\operatorname{trn} \mathrm{C}-\mathrm{GCA}$ & trnS-GCU & trnH-GUG \\
\hline & & $\operatorname{trnK-UUU~}$ & $\operatorname{trn} \mathrm{Q}-\mathrm{UUG}$ & $\operatorname{trnf\mathrm {M}-\mathrm {CAU}}$ & $\operatorname{trn} \mathrm{G}-\mathrm{GCC}$ & trnS-UGA \\
\hline & & trnS-GGA & $\operatorname{trn} \mathrm{F}-\mathrm{GAA}$ & trnM-CAU & $\operatorname{trn} \mathrm{L}-\mathrm{CAA} *$ & \\
\hline & & $\operatorname{trnI-GAU} *, \mathrm{a}$ & trnL-UAG & & & \\
\hline \multirow{6}{*}{ Other Genes } & RNA processing & matK & & & & \\
\hline & $\begin{array}{l}\text { Carbon } \\
\text { metabolism }\end{array}$ & cem $\mathrm{A}$ & & & & \\
\hline & $\begin{array}{l}\text { Fatty acid } \\
\text { synthesis }\end{array}$ & $a c c \mathrm{D}$ & & & & \\
\hline & Proteolysis & $c l p P^{* *}$ & & & & \\
\hline & $\begin{array}{l}\text { Component of TIC } \\
\text { complex }\end{array}$ & $y c f 1^{\mathrm{a}}$ & & & & \\
\hline & $\begin{array}{l}\text { Hypothetical } \\
\text { proteins }\end{array}$ & $y c f 2^{a}$ & $Y_{c f 15}$ & & & \\
\hline
\end{tabular}

* Gene with one intron, ${ }^{* *}$ gene with two introns, ${ }^{\text {a }}$ gene with two copies, same genes in all Withania species.

\subsection{Divergence Hotspots in Withania}

Our comparison showed that all Withania genomes had similar nucleotide compositions in all structural (LSC, SSC, and IR) and coding regions, which extended even to IGSs (Table S2). The number of substitutions ranged between 25 and 116, while substitution types were shared among species (Table 3). A/G and C/T SNPs occurred frequently among the genomes (Table 3), while the ratio of Ts and Tv in the plastomes ranged from 1.04 to 1.25 in the LSC and between 0.5 and 1.5 in the SSC; the ratio varied from 1.3 to 2 in the IR region (Table S3). In general, Ts were more frequent in Withania, consistent with observations in other plant species [61,62]. Indels were frequent in the LSC region and their number ranged from 32 to 46 . The IRs contained only a few indels (Table 4). This may have been due to the observation that IR sequences evolve under concerted evolution compared to LSC and SSC regions that contain more substitutions [63]. When all positions with single- or multinucleotide 
variations as SNPs were considered, 207 SNPs were identified, which corresponds to a mean SNP frequency of $0.2070 \mathrm{SNPs} / \mathrm{kb}$ in Withania species. Indels showed a mean frequency of $0.116 / \mathrm{kb}$.

Table 3. Substitution and their distribution in Withania plastomes, compared to the W. somnifera as reference.

\begin{tabular}{cccc}
\hline Types & W. coagulans & W. adpressa & W. riebeckii \\
\hline $\mathrm{A} / \mathrm{G}$ & 4 & 19 & 28 \\
\hline $\mathrm{C} / \mathrm{T}$ & 10 & 15 & 30 \\
\hline $\mathrm{A} / \mathrm{C}$ & 3 & 11 & 18 \\
\hline $\mathrm{C} / \mathrm{G}$ & 2 & 2 & 3 \\
\hline $\mathrm{G} / \mathrm{T}$ & 4 & 14 & 25 \\
\hline $\mathrm{A} / \mathrm{T}$ & 2 & 5 & 12 \\
\hline Total & 25 & 66 & 116 \\
\hline LSC & 20 & 43 & 79 \\
\hline SSC & 5 & 20 & 30 \\
\hline IR & 0 & 3 & 7 \\
\hline
\end{tabular}

Table 4. Insertions and deletions among Withania species compared to the W. somnifera reference genome.

\begin{tabular}{cccc}
\hline & W. coagulans & Indel Length (bp) & Indel Average Length \\
\hline LSC & 27 & 133 & 4.926 \\
\hline SSC & 3 & 61 & 20.33 \\
\hline IR & 2 & 82 & 41.00 \\
\hline & W. adpressa & Indel Length (bp) & Indel Average Length \\
\hline LSC & 27 & 143 & 5.296 \\
\hline SSC & 6 & 11 & 1.833 \\
\hline IR & 5 & 68 & 13.60 \\
\hline & W. riebeckii & Indel Length (bp) & Indel Average Length \\
\hline LSC & 34 & 213 & 5.917 \\
\hline SSC & 6 & 103 & 17.16 \\
\hline IR & 4 & 106 & 26.50 \\
\hline
\end{tabular}

The indels and SNP mutational events in the plastome showed uneven distributions and clustered as "hotspots" [64,65]. These fast evolving regions are ideally suited for DNA barcoding [66]. The IGS were more polymorphic (average $\pi=0.0027$ ) than protein-coding regions $(\pi=0.0011)$ and introns (average $\pi=0.0015$ ). Among the Withania species, the values ranged from 0.0003 ( $p s a \mathrm{~B}$ ) to 0.0119 (ndhl-ndhA region; Figure 4). We selected the 10 most polymorphic regions for further investigation based on the analysis of mutation rates of the complete chloroplast genome sequences (Table 5). From the selected regions, nine were IGSs, and one was a protein-coding gene (rps15). We assessed the efficacy of these regions to discriminate among the four species of Withania and found that three regions ( $r p s 4-t r n \mathrm{~T}$, trn $\mathrm{M}-a t p \mathrm{E}$, and $r p s 15)$ provided enough information for successful barcoding.

We also investigated the Ks and Ka substitutions and their ratio (Ka/Ks; Table S4). We selected 77 protein-encoding genes for further analysis and observed that 69 genes had $\mathrm{Ks}=0$ and 58 had $\mathrm{Ka}=0$, while 72 genes had both $\mathrm{Ks}$ and $\mathrm{Ka}=0$. Of the protein-encoding genes, four $(a c c \mathrm{D}, y c f 2, y c f 1$, and $n d h \mathrm{~F})$ had $\mathrm{Ka} / \mathrm{Ks}$ ratios $>1$. ycf 1 and $p s b \mathrm{C}$ showed $\mathrm{Ka} / \mathrm{Ks}$ ratios $>0-1$ for $W$. riebeckii, $n d h \mathrm{~F}$ for $W$. coagulans, and rps 15 for $W$. adpressa and $a c c \mathrm{D}, y c f 2$ showed $\mathrm{Ka} / \mathrm{Ks}>0$ for $W$. adpressa and $W$. riebeckii, and rpoC2 for $W$. coagulans and $W$. riebeckii. The low divergence of most chloroplast genes showed signs of purifying selection to conserve the sequence and function of proteins related to photosynthesis. 


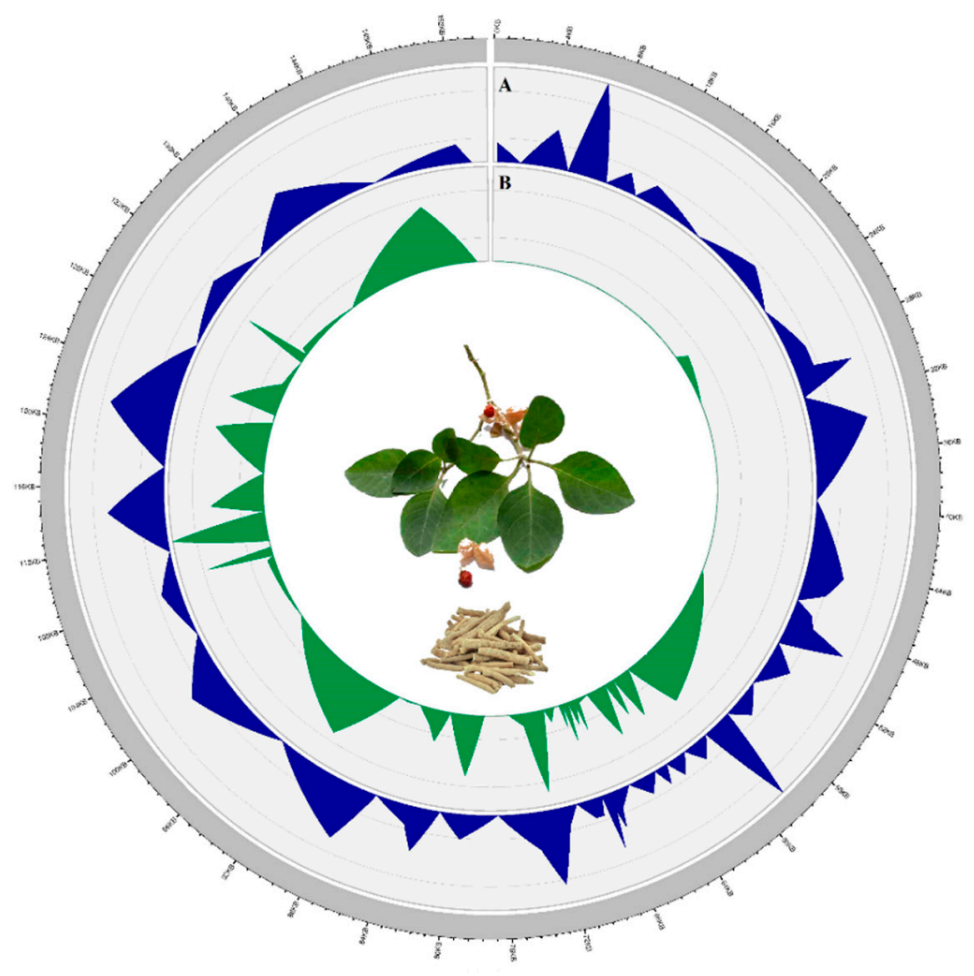

Figure 4. Circular visualization of the distribution of polymorphisms among Withania species. The plastome is shown as a size-proportioned (bp) grey bar in the outer circle. In the inner circle, the values of the (A) average number of nucleotide differences per site or nucleotide diversity $(\pi)$ and (B) indel diversity are shown with a $100 \mathrm{bp}$ window size.

Table 5. Mutational hotspots among Withania species.

\begin{tabular}{ccccc}
\hline S. No & Region & Nucleotide Diversity & T. No's of Mutation & Region Length \\
\hline 1 & $n d h \mathrm{I}-n d h \mathrm{~A}$ & 0.0119 & 2 & 84 \\
\hline 2 & $t r n$ Y-GUA-trnE-UUC & 0.0085 & 1 & 59 \\
\hline 3 & $r p l 14-r p l 16$ & 0.0080 & 2 & 125 \\
\hline 4 & $r p s 19-r p l 2$ & 0.0071 & 1 & 70 \\
\hline 5 & $r p s 15$ & 0.0064 & 3 & 261 \\
\hline 6 & $t r n$ M-CAU-atpE & 0.0053 & 2 & 221 \\
\hline 7 & $r p s 4-t r n$ T-UGU & 0.0051 & 3 & 364 \\
\hline 8 & $t r n$ Q-UUG- $p s b \mathrm{~K}$ & 0.0048 & 3 & 346 \\
\hline 9 & $n d h$ H- $r p s 15$ & 0.0045 & 1 & 111 \\
\hline 10 & $t r n$ G-GCC-trnR-UCU & 0.0041 & 1 & 164 \\
\hline
\end{tabular}

\subsection{Repeat Structure and Analyses}

Chloroplast repeat sequences are important sources of variation for evolutionary studies, plant breeding, and construction of linkage maps [67-69]. We performed a microsatellite analysis that revealed shared microsatellite loci ranging from 376 (W. coagulans) to 379 (W. adpressa). Poly-A and T SSR motifs were frequent in Withania chloroplast genome sequences, while AT/TA dinucleotide stretches were also highly abundant. The mononucleotide motifs occurred in 7-17-unit repeats, while dinucleotide repeats had a frequent 4-5-units, whereas other types of SSRs were present mainly in 3-5-unit repeats. Most SSRs occurred in the LSC, followed by IR and SSC (Figure 5) (Table S5). REPuter was also employed to locate further tandem repeats in all Withania species. A total of 66 oligonucleotide 
repeats were found among Withania species. The $\mathrm{F}$ and $\mathrm{P}$ repeats were present in large numbers in all species. The oligonucleotide repeats were variable in size (30-60 bp) and a large fraction of the repeats was located in the LSC and existed in IGS regions, followed by gene, intron, and coding DNA sequence (CDS) regions (Figure 6; Table S7). The number of tandem repeats varied from 22 to $25 \mathrm{bp}$ among Withania species (Figure 7; Table S6).

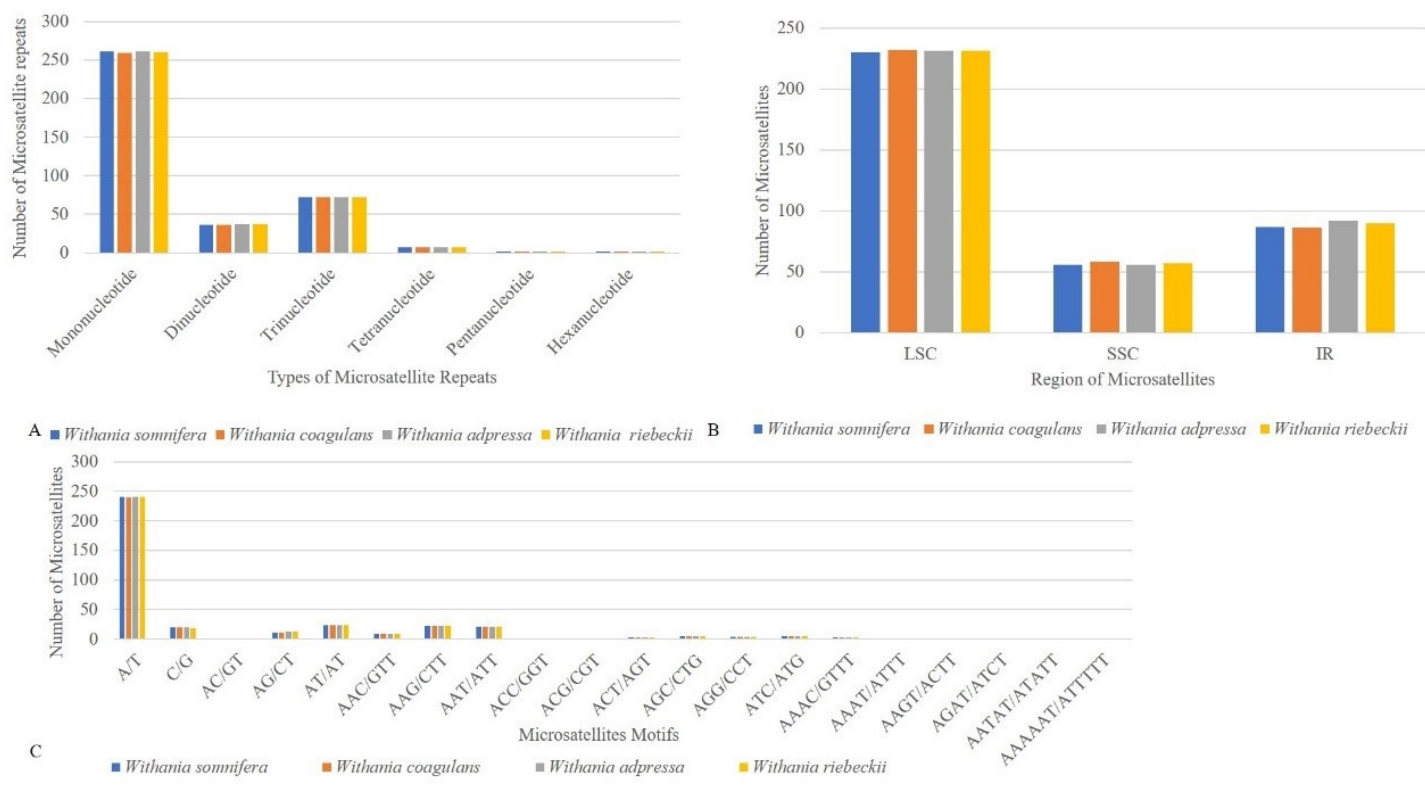

Figure 5. Comparative analysis of microsatellite repeats among Withania species. (A) Total number of microsatellites and their classification according to the number of repeat units. (B) The distribution of microsatellites among structural regions of the plastome. (C) Repeat unit composition of Withania microsatellites.
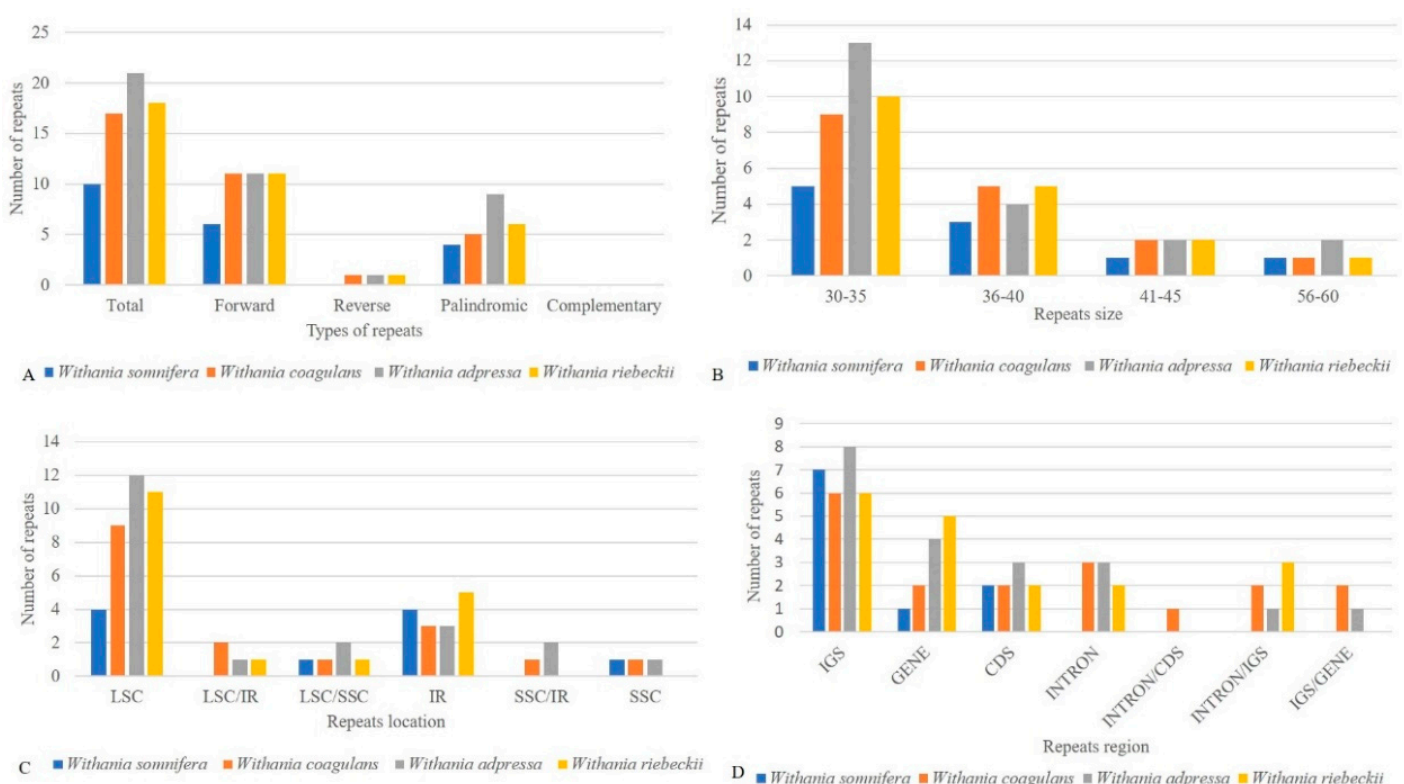

Figure 6. (A) The total number of oligonucleotide repeats among Withania species and their distribution according to specific characteristics. (B) The distribution of repeats in size ranges. (C) The number of repeats grouped according to their location in each structural region (D) The distribution of repeats in intergenic spacer regions (IGS), genes, coding DNA sequences (CDS), and introns and their proportionate occurrence. 


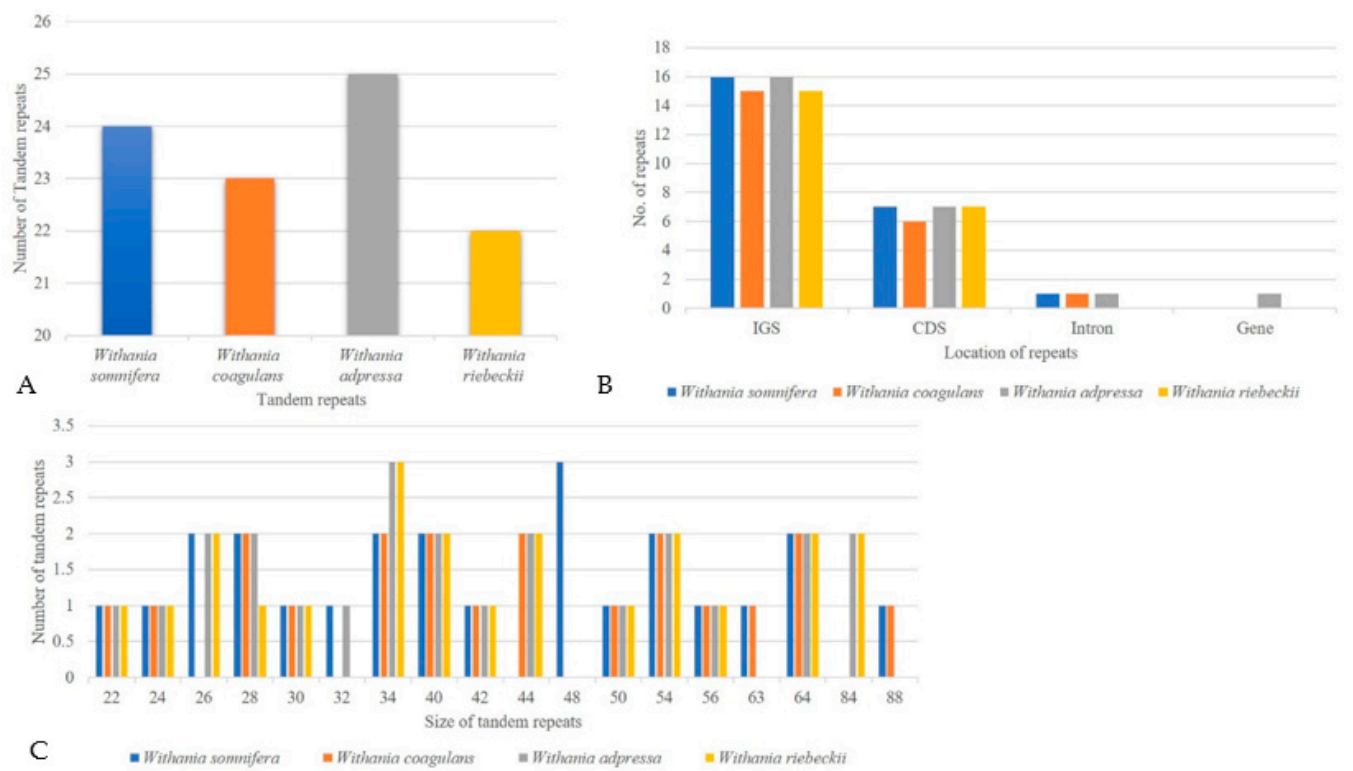

Figure 7. The assessment of tandem repeats (A) The total number of tandem repeats and (B) their distribution among functional regions of the plastome. (C) Tandem repeat number, size, and distribution.

\subsection{Comparative Plastomics and Inverted Repeat Boundaries}

The plastome of land plants has a conserved quadripartite structure while variation frequently occurs in a form of expansion and contraction of the junction sites that could rarely even lead to the loss of the entire IR regions [70,71]. The size of each structural element of the plastome (LSC, SSC, and IR) shows variation at the junction sites JL (LSC/IR) and JS (IR/SSC). Studying these boundaries among plant linages could broaden our knowledge about chloroplast genome evolution and speciation processes [72]. Syntenies among the junction sites could be conserved between species and could explain relationships among them [73]. To investigate such events, we compared the JL (LSC/IR) and JS (IR/SSC) junction sites of Withania plastomes (Figure 8). The resemblance at junctions revealed the close resemblance among the Withania species. The rps19 gene was found at the junction site of JLB (LSC/IRb), and a portion of this gene (8-59 bp) was copied in the IRa in all Withania genomes. The $n d h \mathrm{~F}$ gene was entirely present in the SSC region in W. somnifera and W. adpressa, but in W. coagulans (5 bp) and $W$. riebeckii ( $3 \mathrm{bp}$ ) it was located in the IRb region.

\subsection{Putative RNA-Editing Sites}

RNA editing is the molecular processes that can alter the sequence of the transcribed RNA by insertion, deletion, or nucleotide substitution [46]. RNA editing aids in creating transcripts and maintaining protein diversity [74], thus several sites are conserved in the plastome of angiosperms [75]. To examine the RNA editing in Withania species, we predicted putative sites in the plastomes using PREP-cp. This revealed 37 putative sites in 15 genes of $W$. somnifera, while 35, 39, and 37 editing sites were found in 13 genes of $W$. coagulans and in 14 genes of $W$. adpressa and W. riebeckii, respectively. The gene $c l p \mathrm{P}$ has editing sites only in W. somnifera and ccs A only in W. adpressa. Among Withania species $n d h \mathrm{~B}(9), n d h \mathrm{D}(7)$, and $r p o \mathrm{~B}(5)$ had the highest number of RNA-editing sites. All species had high levels of conversion for serine (Ser) to leucine (Leu; 60\%, 53.8\%, and 59.4\%, respectively), followed by proline (Pro) to Leu (14.28\%, 17.94\%, and $16.21 \%$, respectively), and Ser to phenylalanine (Phe; $8.57 \%, 10.2 \%$, and $10.8 \%$, respectively). Of the putative RNA-editing sites detected, $33(94.2 \%)$, $34(87.1 \%)$, and $33(89.1 \%)$ codons were substituted on the second nucleotide and two $(5.71 \%)$, five $(12.8 \%)$, and four $(10.81 \%)$ codons were substituted in the first nucleotide in W. coagulans, W. adpressa, and W. riebeckii, respectively. Many amino acids were converted from Ser to Leu helping to form hydrophobic amino acids, e.g., valine (Val), Leu, and Phe (Table S8). 


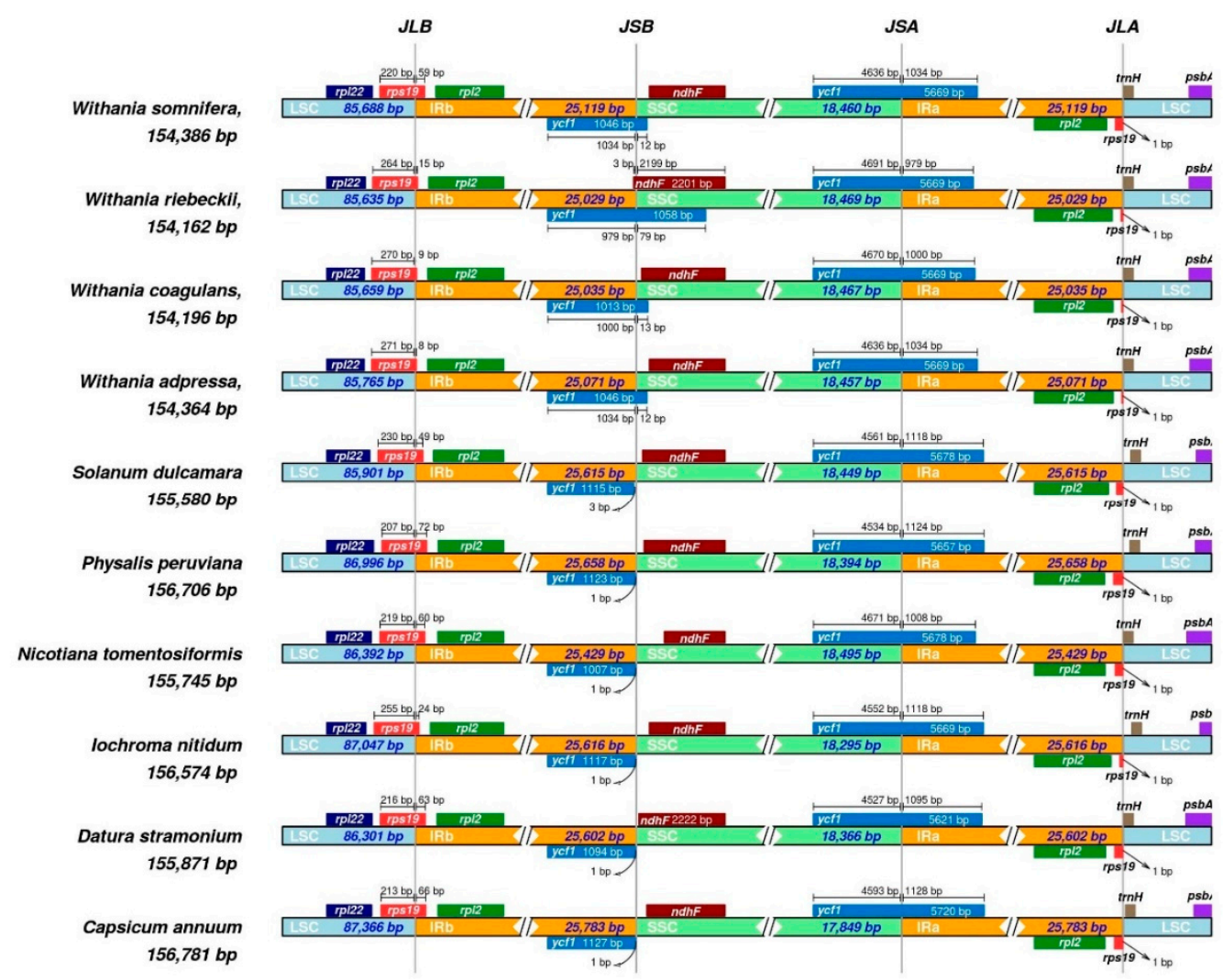

Figure 8. The comparative assessment of junction sites among six Withania species and six outgroups of Solanaceae. Genes are represented by boxes above (negative-strand) and below (positive-strand) the proportionate line. The size of each gene and their relative position at the junctions are shown in base pairs (bp). The figure shows the conservation of the junctions among Withania species with mild shifts at the JSB (IRb/SSC).

\subsection{Phylogenetic Analysis}

We performed maximum-likelihood (ML) and Bayesian analysis for phylogenetic reconstruction for 19 Solanaceae species, based on selected protein-coding gene sequences extracted from whole-plastome sequences. Based on a 69,582-bp alignment, our tree was reconstructed and resolved identical topologies for both methods and a phylogenetic tree were supported by high bootstrap values and posterior probabilities (Figure 9). The genus Withania was represented by W. adpressa, native to North Africa, Morocco, and Algeria, W. coagulans from the eastern distribution area, W. riebeckii native to the island of Socotra, Jemen, and finally, the widespread W. somnifera. Our phylogenetic analysis with limited taxonomic sampling resolved Withania as a monophyletic of the genus. However, further sampling is needed to investigate the relationship of the allied genera especially from Athenaea Sendtn., Aureliana Sendtn., and Mellissia Hook. f. not included in our analysis, which were shown to be closely related to Withania [76]. Our results were consistent with previous findings based on plastid intergenic at $p \mathrm{~B}-r b c \mathrm{~L}$ spacer [77], $n d h \mathrm{~F}$ and $\operatorname{trn} \mathrm{LF}$ [1], or whole plastome sequences [18]. 


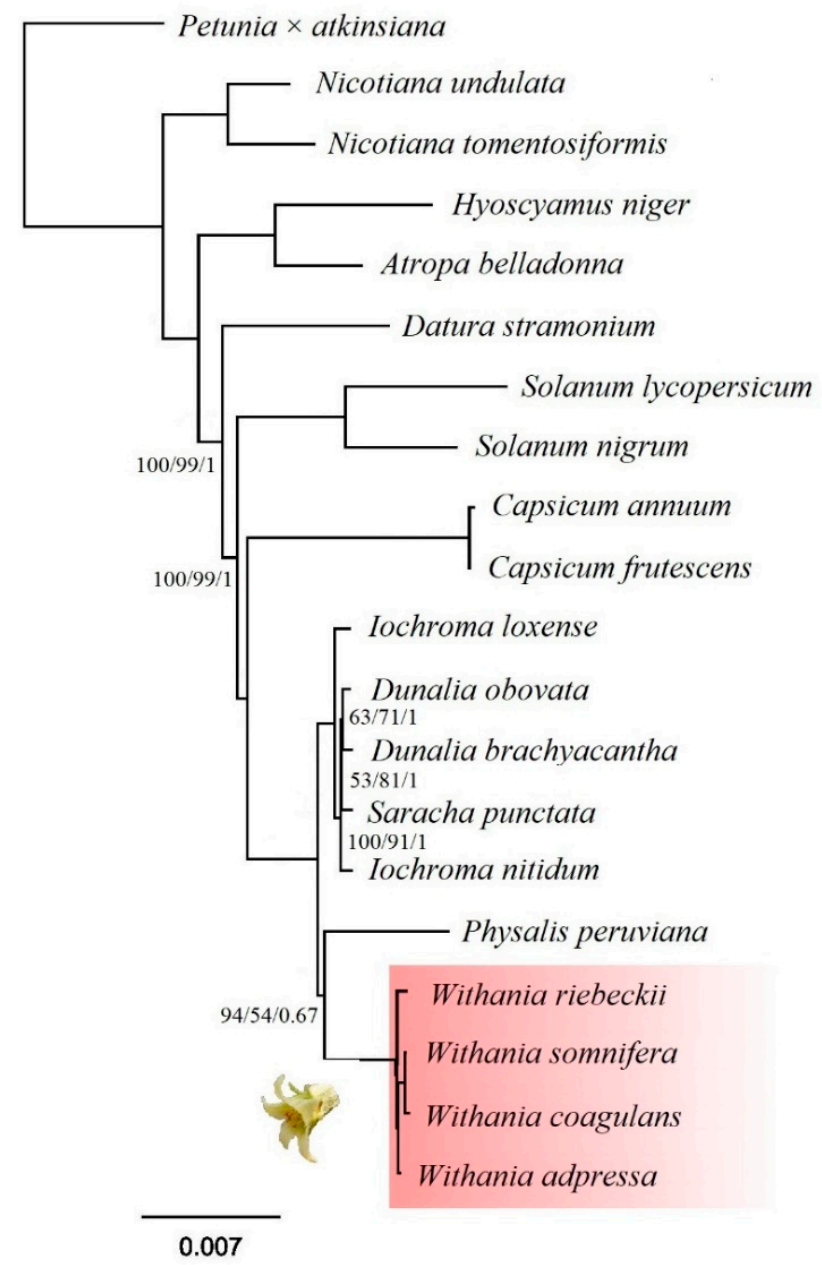

Figure 9. Maximum likelihood (ML) tree reconstructed among 19 species of Solanaceae based on 74 protein-coding genes. Bootstrap, SH-aLRT values and Bayesian posterior probabilities are indicated at each node as UFBoot/SH-aLRT/PP. Unmarked nodes have maximum support values. The scale bar is proportional to substitution per site.

\section{Discussion}

Chloroplast DNA (cpDNA) is frequently used in plant phylogenetics at various levels (i.e., generic level and above) $[19,66,78]$. It has also been used in Solanaceae systematics to infer family level phylogenetic relationships and to identify major clades and dispersal events [79]. Thus, we characterized, annotated, and analyzed the plastome of Withania species, which was further used in phylogenetic inference. Withania species belong to a rather diverse and widely distributed Withaninae clade within the so-called physaloid group. Species of the genus Withania are morphologically similar: the flowers are found in lateral clusters (fascicles) lacking a supporting inflorescence stem (peduncle). The flower petals (corollas) are bell or elongated cup-shaped, sometimes urn-shaped, circular and flattened (rotate), or trumpet-shaped (salverform), while the filaments often form nectar grooves with lateral attachments. The Withaninae clade consists of approximately seven small often monotypic genera mostly found in the Old World, e.g., Tubocapsicum (Wettst.) Makino, Mellissia, Aureliana, or Discopodium Hochst. D'Arcy [80] considered Withania to be one of the truly Old-World genera, while Symon [81] regarded it as a distinctive African Gondwanan element. Withania has a center of distribution around Spain, NW Africa extending to the Canary Islands, while another is located in India, the southern region of the Arabian Peninsula, and the Horn of Africa. The phylogenetic relationships within the genus are poorly known, and the biology, chromosome numbers, and the exact number of species are also lacking. Chromosome counts showed that most species of Withania are polyploids with $2 n=2 x=$ 
48 [82], derived from the $\mathrm{x}=12$ haploid chromosome number typical for the majority of Solanaceae species. In addition to the currently accepted Withania taxa, there are 35 unresolved botanical names that need further investigation to clarify the taxonomy of the genus.

In the Hepper's treatment [83], Withania consisted of 10 species, which were extended by Hunziker [84] with the addition of nine mesophytes from the genera Mellissia Hook. and Physaliastrum Makino. These additions extended the geographical range of the genus from the Canary Islands in the west, through Asia to China and Japan in the east. Symon [81] also emphasized the similarity of Mellissia (a critically endangered endemic of St Helena) to Withania but retained them as distinct genera. In contrast, Hunziker [84] included Mellissia within Withania and molecular results support this placement [1]. There is no consensus on the positions of the small clades related to Withania, while its closest relatives are also debated. In our analysis, Withania formed a clade together with Physalis, similarly to the findings of Deanna et al. [82], although this branching is supported by only weak bootstrap values.

Plastome sequences could be used as tools to further elucidate species boundaries and investigate the phylogenetic relationships among the small clades of Withaninae and resolve the taxonomic debate over the placement of Melissia and other monotypic genera. For such barcoding studies our results could provide valuable reference genomes for assemblies. The hotspot regions described in our study could be useful in such phylogenetic or even population genetic investigations. It was previously demonstrated that identifying highly variable regions by comparative plastomics could provide reveal loci that could be used in DNA barcoding [85-87]. Such divergent hotspots in the plastomes can be applied for DNA barcoding at the generic level $[29,88-90]$. Thus, the set of 10 polymorphic regions identified among Withania in our study could be applied for DNA barcoding. Moreover, similar to the aforementioned studies, our identified mutational hotspots showed high discrimination properties and from the 10 mutational hotspots, three regions were found to be sufficient for the identification of the four Withania species included in our study.

We analyzed Ks substitutions and Ka substitutions of protein-coding genes and recorded greater Ks substitutions relative to the Ka substations. Such observations are essential markers in evolution for defining slow- and fast-evolving genes [91]. The Ka/Ks ratio also informs us about the selection pressure on these genes. When the $\mathrm{Ka} / \mathrm{Ks}$ value is minimal, it represents purifying selection, while values similar to it or equal to 1 represent neutral evolution, and values greater than 1 denote positive selection [85]. Most plastid genes showed a minimal $\mathrm{Ka} / \mathrm{Ks}$ ratio $(<1)$, demonstrating that purifying selection is acting over these genes, due to functional constraints of the plastome. However, $\operatorname{at} p \mathrm{~B}, n d h \mathrm{D}$, $n d h \mathrm{~F}, r p o \mathrm{~A}, r p o \mathrm{C} 1, r p s 2$, and $r p s 12$ showed greater $\mathrm{Ka} / \mathrm{Ks}$ values $(>1)$, possibly indicating selective pressure acting over these genes that was previously proposed in other groups [92-95]. Our sampling in the Withania clade was limited to explore the biological causes of the elevated $\mathrm{Ka} / \mathrm{Ks}$ ratios observed in cases involving these genes. Here, we suggest that the following set of genes could be the principal candidates in investigations of these environmental interactions and their effects on plastid genes. Such investigations should include a nearly complete phylogenetic sampling of Withania and consider the effects of arbitrary variations in Ka and Ks values leading to false positive inferences and values higher than 1 . These shortcoming can be bypassed by complete sampling and additional tests of selective pressure also stressed here for future analyses.

\section{Conclusions}

It has been shown that DNA barcoding can fail in complicated groups [96]. Solanaceae includes many species complexes with tangled taxonomy such examples of species groups can be found in potatoes and its wild relatives, e.g., Solanum brevicaule complex [97], or the eggplant and its wild relatives (S. melongena complex [98]) but in other clades of the family for example in the genus Petunia [99] or closely related Physalis [100]. In these complicated groups well known plastid barcode regions (e.g.,

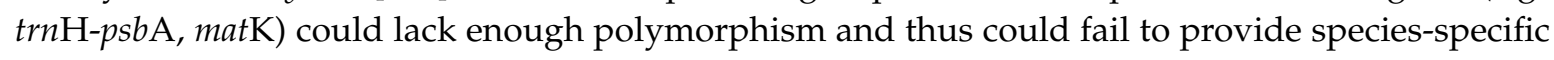
information necessary for differentiation [96]. It has been shown that plastid genome based "super 
barcoding" could overcome these difficulties and could differentiate species in difficult taxonomic groups. This approach has been successfully employed in the $S$. melongena complex to trace the ancestors of cultivated eggplant and differentiate closely related wild species [98]. Here, we compared the complete plastome sequences of four Withania species and investigated if plastid genomes based "super barcoding" could be applied among closely related ashwagandha species. The structure of these genomes showed synteny with a previously reported organization of Solanaceae species. We identified sequence divergence hotspots and located repeat sequences and indels in the plastomes of Withania species. These regions may constitute a useful means to develop suitable molecular markers for species identification and DNA barcoding of ashwagandha medicinal products. It is hoped that our study will aid the development of DNA barcoding markers to clarify the taxonomic identity of Withania species in medicinal plant production. Such plastome-based "super barcoding" could be repeatable, reliable, and sensitive enough to distinguish look-alike species of ashwagandha.

Supplementary Materials: The following are available online at http://www.mdpi.com/2223-7747/9/6/752/s1, Table S1: Base composition in the chloroplast genome of W. somnifera, W. coagulans, W. adpressa and W. riebeckii; Table S2: Codon usage in the chloroplast genome of W. somnifera, W. coagulans, W. adpressa and W. riebeckii; Table S3: Putative RNA editing sites composition in the chloroplast genome of W. somnifera, W. coagulans, W. adpressa and W. riebeckii; Table S4: Comparison of synonymous and non-synonymous substitution in Withania species S5: Microsatellites loci in the chloroplast genome of W. somnifera, W. coagulans, W. adpressa and W. riebeckii; Table S6: Oligonucleotide repeats in chloroplast genomes of W. somnifera, W. coagulans, W. adpressa and W. riebeckii; Table S7: Tandem Repeat sequences in the chloroplast genome of $W$. somnifera, $W$. coagulans, $W$. adpressa and $W$. riebeckii; Table S8: The distribution and characteristics of SNPs found among Withania plastid genomes; Table S9: NCBI GenBank accession numbers used in this study; Table S10: Model selected for each data partition identified by software Partition Finder for protein-coding chloroplast genes and intron regions in maximum likelihood (ML) analysis and Bayesian inference (BI).

Author Contributions: Conceptualization: F.M., B.M., P.P.; Formal analysis: F.M., A., Z.U., P.P.; Investigation: F.M., A., Z.U., P.P.; Methodology: F.M., A., Z.U., P.P.; Project administration: B.M., P.P., Y.B.; Resources: B.M., P.P., Y.B.; Software: F.M., A., Z.U., P.P.; Supervision: B.M., P.P.; Validation: F.M., P.P.; Visualization: F.M., P.P.; Writing original draft: F.M., A., P.P.; Writing-review and editing: F.M., A., P.P. All authors have read and agreed to the published version of the manuscript.

Funding: This research was funded by the National Key Research and Development Program of China (2016YFE0206600 to Y.B.); The 13th Five-year Informatization Plan of the Chinese Academy of Sciences (XXH13505-05 to Y.B.); The Open Biodiversity and Health Big Data Program of IUBS (to Y.B.).

Acknowledgments: We acknowledge the DNA4 Technologies LLC (Withania adpressa and Withania riebeckii) for sequencing and deposition of the raw sequencing data in the public repository of the National Center of Biotechnology Information. The authors thank James Thompson for editing the manuscript.

Conflicts of Interest: The authors declare that they have no conflict of interest.

\section{References}

1. Olmstead, R.G.; Bohs, L.; Migid, H.A.; Santiago-Valentin, E.; Garcia, V.F.; Collier, S.M. A molecular phylogeny of the Solanaceae. Taxon 2008, 57, 1159-1181. [CrossRef]

2. Olmstead, R.G.; Bohs, L. A summary of molecular systematic research in Solanaceae: 1982-2006. Solanaceae IV: Genomics meets biodiversity. In Proceedings of the VIth International Solanaceae Conference, Madison, WI, USA, 23-27 July 2006; pp. 255-268.

3. Knapp, S.; Bohs, L.; Nee, M.; Spooner, D.M. Solanaceae-A model for linking genomics with biodiversity. Comp. Funct. Genom. 2004, 5, 285-291. [CrossRef]

4. Mirjalili, M.H.; Moyano, E.; Bonfill, M.; Cusido, R.M.; Palazón, J. Steroidal lactones from Withania somnifera, an ancient plant for novel medicine. Molecules 2009, 14, 2373-2393. [CrossRef] [PubMed]

5. Singh, P.; Guleri, R.; Singh, V.; Kaur, G.; Kataria, H.; Singh, B.; Kaur, G.; Kaul, S.C.; Wadhwa, R.; Pati, P.K. Biotechnological interventions in Withania somnifera (L.) dunal. Biotechnol. Genet. Eng. Rev. 2015, 31, 1-20. [CrossRef] [PubMed]

6. Uddin, Q.; Samiulla, L.; Singh, V.K.; Jamil, S.S. Phytochemical and pharmacological profile of Withania somnifera dunal: A review. J. Appl. Pharm. Sci. 2012, 2, 170-175.

7. Maurya, R. Chemistry and pharmacology of Withania coagulans: An ayurvedic remedy. J. Pharm. Pharm. 2010, 62, 153-160. [CrossRef] [PubMed] 
8. Ul-Haq, I.; Youn, U.J.; Chai, X.; Park, E.-J.; Kondratyuk, T.P.; Simmons, C.J.; Borris, R.P.; Mirza, B.; Pezzuto, J.M.; Chang, L.C. Biologically active withanolides from Withania coagulans. J. Nat. Prod. 2013, 76, 22-28. [CrossRef] [PubMed]

9. Rehman, S.; Keefover-Ring, K.; Haq, I.U.L.; Dilshad, E.; Khan, M.I.; Akhtar, N.; Mirza, B. Drier climatic conditions increase withanolide content of Withania coagulans enhancing its inhibitory potential against human prostate cancer cells. Appl. Biochem. Biotechnol. 2019, 188, 460-480. [CrossRef] [PubMed]

10. Shinwari, Z.K. Medicinal plants research in Pakistan. J. Med. Plants Res. 2010, 4, 161-176.

11. Raclariu, A.C.; Heinrich, M.; Ichim, M.C.; de Boer, H. Benefits and limitations of DNA barcoding and metabarcoding in herbal product authentication. Phytochem. Anal. 2018, 29, 123-128. [CrossRef]

12. Li, M.; Cao, H.; But, P.P.H.; Shaw, P.C. Identification of herbal medicinal materials using DNA barcodes. J. Syst. Evol. 2011, 49, 271-283. [CrossRef]

13. Jin, S.; Daniell, H. The engineered chloroplast genome just got smarter. Trends Plant. Sci. 2015, 20, 622-640. [CrossRef] [PubMed]

14. Cooper, G. Chloroplasts and Other Plastids in the Cell: A Molecular Approach, 2nd ed.; Sinauer Associates: Sunderland, MA, USA, 2000.

15. Palmer, J.D. Comparative organization of chloroplast genomes. Annu. Rev. Genet. 1985, 19, 325-354. [CrossRef]

16. Daniell, H.; Lin, C.-S.; Yu, M.; Chang, W.-J. Chloroplast genomes: Diversity, evolution, and applications in genetic engineering. Genome Biol. 2016, 17, 134. [CrossRef] [PubMed]

17. Oldenburg, D.J.; Bendich, A.J. DNA maintenance in plastids and mitochondria of plants. Front. Plant. Sci. 2015, 6, 883. [CrossRef] [PubMed]

18. Amiryousefi, A.; Hyvönen, J.; Poczai, P. The chloroplast genome sequence of bittersweet (Solanum dulcamara): Plastid genome structure evolution in Solanaceae. PLoS ONE 2018, 13, 1-23. [CrossRef] [PubMed]

19. Abdullah; Shahzadi, I.; Mehmood, F.; Ali, Z.; Malik, M.S.; Waseem, S.; Mirza, B.; Ahmed, I.; Waheed, M.T. Comparative analyses of chloroplast genomes among three Firmiana species: Identification of mutational hotspots and phylogenetic relationship with other species of Malvaceae. Plant. Gene 2019, 19, 100199. [CrossRef]

20. Henriquez, C.L.; Abdullah; Ahmed, I.; Carlsen, M.M.; Zuluaga, A.; Croat, T.B.; Mckain, M.R. Evolutionary dynamics of chloroplast genomes in subfamily Aroideae (Araceae). Genomics 2020, 112, 2349-2360. [CrossRef]

21. Xu, J.-H.; Liu, Q.; Hu, W.; Wang, T.; Xue, Q.; Messing, J. Dynamics of chloroplast genomes in green plants. Genomics 2015, 106, 221-231. [CrossRef]

22. Moore, M.J.; Bell, C.D.; Soltis, P.S.; Soltis, D.E. Using plastid genome-scale data to resolve enigmatic relationships among basal angiosperms. Proc. Natl. Acad. Sci. USA 2007, 104, 19363-19368. [CrossRef]

23. Ravi, V.; Khurana, J.P.; Tyagi, A.K.; Khurana, P. An update on chloroplast genomes. Plant. Syst. Evol. 2008, 271, 101-122. [CrossRef]

24. Mehmood, F.; Abdullah; Shahzadi, I.; Ahmed, I.; Waheed, M.T.; Mirza, B. Characterization of Withania somnifera chloroplast genome and its comparison with other selected species of Solanaceae. Genomics 2020, 112, 1522-1530. [CrossRef] [PubMed]

25. Iram, S.; Hayat, M.Q.; Tahir, M.; Gul, A.; Abdullah; Ahmed, I. Chloroplast genome sequence of Artemisia scoparia: Comparative analyses and screening of mutational hotspots. Plants 2019, 8, 476. [CrossRef] [PubMed]

26. Bansal, K.C.; Saha, D. Chloroplast genomics and genetic engineering for crop improvement. Agric. Res. 2012, 1, 53-66. [CrossRef]

27. Waheed, M.T.; Thönes, N.; Müller, M.; Hassan, S.W.; Razavi, N.M.; Lössl, E.; Kaul, H.P.; Lössl, A.G. Transplastomic expression of a modified human papillomavirus L1 protein leading to the assembly of capsomeres in tobacco: A step towards cost-effective second-generation vaccines. Transgenic Res. 2011, 20, 271-282. [CrossRef] [PubMed]

28. Waheed, M.T.; Ismail, H.; Gottschamel, J.; Mirza, B.; Lössl, A.G. Plastids: The green frontiers for vaccine production. Front. Plant. Sci. 2015, 6, 1005. [CrossRef] [PubMed]

29. Ahmad, I. Evolutionary Dynamics in Taro. Ph.D. Thesis, Massey University, Palmerston North, New Zealand, 2014. 
30. Wambugu, P.W.; Brozynska, M.; Furtado, A.; Waters, D.L.; Henry, R.J. Relationships of wild and domesticated rices (Oryza AA genome species) based upon whole chloroplast genome sequences. Sci. Rep. 2015, 5, 13957. [CrossRef] [PubMed]

31. Murray, M.G.; Thompson, W.F. Rapid isolation of high molecular weight plant DNA. Nucleic Acids Res. 1980, 8, 4321-4325. [CrossRef]

32. Andrews, S. FASTQC. A Quality Control Tool for High throughput Sequence Data. Available online: https://www.bioinformatics.babraham.ac.uk/projects/fastqc/ (accessed on 14 February 2020).

33. Zerbino, D.R.; Birney, E. Velvet: Algorithms for de novo short read assembly using de Bruijn graphs. Genome Res. 2008, 18, 821-829. [CrossRef]

34. Kearse, M.; Moir, R.; Wilson, A.; Stones-Havas, S.; Cheung, M.; Sturrock, S.; Buxton, S.; Cooper, A.; Markowitz, S.; Duran, C.; et al. Geneious basic: An integrated and extendable desktop software platform for the organization and analysis of sequence data. Bioinformatics 2012, 28, 1647-1649. [CrossRef]

35. Tillich, M.; Lehwark, P.; Pellizzer, T.; Ulbricht-Jones, E.S.; Fischer, A.; Bock, R.; Greiner, S. GeSeq-versatile and accurate annotation of organelle genomes. Nucleic Acids Res. 2017, 45, W6-W11. [CrossRef] [PubMed]

36. Shi, L.; Chen, H.; Jiang, M.; Wang, L.; Wu, X.; Huang, L.; Liu, C. CPGAVAS2, an integrated plastome sequence annotator and analyzer. Nucleic Acids Res. 2019, 47, W65-W73. [CrossRef] [PubMed]

37. Lowe, T.M.; Chan, P.P. tRNAscan-SE On-line: Integrating search and context for analysis of transfer RNA genes. Nucleic Acids Res. 2016, 44, W54-W57. [CrossRef] [PubMed]

38. Laslett, D.; Canback, B. ARAGORN, a program to detect tRNA genes and tmRNA genes in nucleotide sequences. Nucleic Acids Res. 2004, 32, 11-16. [CrossRef] [PubMed]

39. Cheong, W.-H.; Tan, Y.-C.; Yap, S.-J.; Ng, K.-P. Clico FS: An interactive web-based service of Circos. Bioinformatics 2015, 31, 3685-3687. [CrossRef]

40. Li, H.; Durbin, R. Fast and accurate short read alignment with burrows-wheeler transform. Bioinformatics 2009, 25, 1754-1760. [CrossRef]

41. Milne, I.; Bayer, M.; Cardle, L.; Shaw, P.; Stephen, G.; Wright, F.; Marshall, D. Tablet-next generation sequence assembly visualization. Bioinformatics 2009, 26, 401-402. [CrossRef]

42. Zhang, Z.; Zhao, W.; Xiao, J.; Bao, Y.; He, S.; Zhang, G.; Li, Y.; Zhao, G.; Chen, R.; Gao, Y.; et al. Database resources of the national genomics data center in 2020. Nucleic Acids Res. 2020, 48, D24-D33.

43. Katoh, K.; Kuma, K.I.; Toh, H.; Miyata, T. MAFFT version 5: Improvement in accuracy of multiple sequence alignment. Nucleic Acids Res. 2005, 33, 511-518. [CrossRef]

44. Rozas, J.; Ferrer-Mata, A.; Sanchez-DelBarrio, J.C.; Guirao-Rico, S.; Librado, P.; Ramos-Onsins, S.E.; Sanchez-Gracia, A. DnaSP 6: DNA sequence polymorphism analysis of large data sets. Mol. Biol. Evol. 2017, 34, 3299-3302. [CrossRef]

45. Amiryousefi, A.; Hyvönen, J.; Poczai, P. IRscope: An online program to visualize the junction sites of chloroplast genomes. Bioinformatics 2018, 34, 3030-3031. [CrossRef] [PubMed]

46. Darzentas, N. Circoletto: Visualizing sequence similarity with Circos. Bioinformatics 2010, 26, $2620-2621$. [CrossRef] [PubMed]

47. Mower, J.P. The PREP suite: Predictive RNA editors for plant mitochondrial genes, chloroplast genes and user-defined alignments. Nucleic Acids Res. 2009, 37, W253-W259. [CrossRef] [PubMed]

48. Beier, S.; Thiel, T.; Münch, T.; Scholz, U.; Mascher, M. MISA-web: A web server for microsatellite prediction. Bioinformatics 2017, 33, 2583-2585. [CrossRef]

49. Kurtz, S.; Choudhuri, J.V.; Ohlebusch, E.; Schleiermacher, C.; Stoye, J.; Giegerich, R. REPuter: The manifold applications of repeat analysis on a genomic scale. Nucleic Acids Res. 2002, 29, 4633-4642. [CrossRef]

50. Benson, G. Tandem repeats finder: A program to analyze DNA sequences. Nucleic Acids Res. 1999, 27, 573-580. [CrossRef]

51. Nguyen, L.-T.; Schmidt, H.A.; von Haeseler, A.; Minh, B.Q. IQ-TREE: A fast and effective stochastic algorithm for estimating maximum-likelihood phylogenies. Mol. Biol. Evol. 2015, 32, 268-274. [CrossRef]

52. Kalyaanamoorthy, S.; Minh, B.Q.; Wong, T.K.F.; von Haeseler, A.; Jermiin, L.S. ModelFinder: Fast model selection for accurate phylogenetic estimates. Nat. Methods 2017, 14, 587-589. [CrossRef]

53. Hoang, D.T.; Chernomor, O.; von Haeseler, A.; Minh, B.Q.; Vinh, L.S. UFBoot2: Improving the ultrafast bootstrap approximation. Mol. Biol. Evol. 2018, 35, 518-522. [CrossRef] 
54. Dereeper, A.; Guignon, V.; Blanc, G.; Audic, S.; Buffet, S.; Chevenet, F.; Dufayard, J.-F.; Guindon, S.; Lefort, V.; Lescot, M.; et al. Phylogeny.fr: Robust phylogenetic analysis for the non-specialist. Nucleic Acids Res. 2008, 36, W465-W469. [CrossRef]

55. Lemoine, F.; Correia, D.; Lefort, V.; Doppelt-Azeroual, O.; Mareuil, F.; Cohen-Boulakia, S.; Gascuel, O. NGPhylogeny.fr: New generation phylogenetic services for non-specialists. Nucleic Acids Res. 2019, 47, W260-W265. [CrossRef] [PubMed]

56. Lanfear, R.; Calcott, B.; Ho, S.Y.W.; Guindon, S. PartitionFinder: Combined selection of partitioning schemes and substitution models for phylogenetic analyses. Mol. Biol. Evol. 2012, 29, 1695-1701. [CrossRef] [PubMed]

57. Huelsenbeck, J.P.; Ronquist, F. MRBAYES: Bayesian inference of phylogenetic trees. Bioinformatics 2001, 17, 754-755. [CrossRef] [PubMed]

58. Darriba, D.; Taboada, G.L.; Doallo, R.; Posada, D. jModelTest 2: More models, new heuristics and parallel computing. Nat. Methods 2012, 9, 772. [CrossRef]

59. Qian, J.; Song, J.; Gao, H.; Zhu, Y.; Xu, J.; Pang, X.; Yao, H.; Sun, C.; Li, X.; Li, C.; et al. The complete chloroplast genome sequence of the medicinal plant Salvia miltiorrhiza. PLoS ONE 2013, 8, e57607. [CrossRef] [PubMed]

60. Abdullah; Mehmood, F.; Shahzadi, I.; Ali, Z.; Islam, M.; Naeem, M.; Mirza, B.; Lockhart, P.; Ahmed, I.; Waheed, M.T. Correlations among oligonucleotide repeats, nucleotide substitutions and insertion-deletion mutations in chloroplast genomes of plant family Malvaceae. J. Syst. Evol. 2020. [CrossRef]

61. Shahzadi, I.; Abdullah; Mehmood, F.; Ali, Z.; Ahmed, I.; Mirza, B. Chloroplast genome sequences of Artemisia maritima and Artemisia absinthium: Comparative analyses, mutational hotspots in genus Artemisia and phylogeny in family Asteraceae. Genomics 2020. [CrossRef]

62. Song, Y.; Chen, Y.; Lv, J.; Xu, J.; Zhu, S.; Li, M. Comparative chloroplast genomes of Sorghum species: Sequence divergence and phylogenetic relationships. Biomed. Res. Int. 2019. [CrossRef]

63. Sun, J.; Chen, M.; Yujiang; Zhao, D.; Tao, J. Characterization of the complete chloroplast genomes of sequences of two diploid species: Paeonia lactiflora 'Da Fugui' and Paeonia ostii 'Fengdan' in the Paeoniaceae Family. J. Hortic. 2018, 5, 4. [CrossRef]

64. Ahmed, I.; Biggs, P.J.; Matthews, P.J.; Collins, L.J.; Hendy, M.D.; Lockhart, P.J. Mutational dynamics of aroid chloroplast genomes. Genome Biol. Evol. 2012, 4, 1316-1323. [CrossRef]

65. Shaw, J.; Lickey, E.B.; Schilling, E.E.; Small, R.L. Comparison of whole chloroplast genome sequences to choose noncoding regions for phylogenetic studies in angiosperms: The tortoise and the hare III. Am. J. Bot. 2007, 94, 275-288. [CrossRef] [PubMed]

66. Hollingsworth, P.M.; Graham, S.W.; Little, D.P. Choosing and using a plant DNA barcode. PLoS ONE 2011, 6, e19254. [CrossRef] [PubMed]

67. Worberg, A.; Quandt, D.; Barniske, A.M.; Löhne, C.; Hilu, K.W.; Borsch, T. Phylogeny of basal eudicots: Insights from non-coding and rapidly evolving DNA. Org. Divers. Evol. 2007, 7, 55-77. [CrossRef]

68. Powell, W.; Morgante, M.; McDevitt, R.; Vendramin, G.G.; Rafalski, J.A. Polymorphic simple sequence repeats regions in chloroplast genomes: Applications to the population genetics of pines. Proc. Natl. Acad. Sci. USA 1995, 92, 7759-7763. [CrossRef]

69. Xue, J.; Wang, S.; Zhou, S.L. Polymorphic chloroplast microsatellite loci in Nelumbo (Nelumbonaceae). Am. J. Bot. 2012, 99, e240-e244. [CrossRef]

70. Zhang, Y.; Du, L.; Liu, A.; Chen, J.; Wu, L.; Hu, W.; Zhang, W.; Kim, K.; Lee, S.-C.; Yang, T.-J.; et al. The Complete chloroplast genome sequences of five Epimedium species: Lights into phylogenetic and taxonomic analyses. Front. Plant. Sci. 2016, 7, 306. [CrossRef]

71. Wang, R.J.; Cheng, C.L.; Chang, C.C.; Wu, C.L.; Su, T.M.; Chaw, S.M. Dynamics and evolution of the inverted repeat-large single copy junctions in the chloroplast genomes of monocots. BMC Evol. Biol. 2008, 8, 36. [CrossRef]

72. Palmer, J.D.; Jansen, R.K.; Michaels, H.J.; Chase, M.W.; Manhart, J.R. Chloroplast DNA variation and plant phylogeny. Ann. Mo. Bot. Gard. 1988, 75, 1180-1206. [CrossRef]

73. Liu, H.; He, J.; Ding, C.; Lyu, R.; Pei, L.; Cheng, J.; Xie, L. Comparative analysis of complete chloroplast genomes of Anemoclema, Anemone, Pulsatilla, and Hepatica revealing structural variations among genera in tribe Anemoneae (Ranunculaceae). Front. Plant. Sci. 2018, 9, 1-16. [CrossRef] 
74. Bundschuh, R.; Altmüller, J.; Becker, C.; Nürnberg, P.; Gott, J.M. Complete characterization of the edited transcriptome of the mitochondrion of Physarum polycephalum using deep sequencing of RNA. Nucleic Acids Res. 2011, 39, 6044-6055. [CrossRef]

75. Zeng, W.H.; Liao, S.C.; Chang, C.C. Identification of RNA editing sites in chloroplast transcripts of Phalaenopsis aphrodite and comparative analysis with those of other seed plants. Plant. Cell Physiol. 2007, 48, 362-368. [CrossRef] [PubMed]

76. Kool, A.; Oxelman, B.; Thulin, M. Phylogeny of Withania (Solanaceae). In Proceedings of the Abstracts XVII International Botanical Congress, Vienna, Austria, 17-23 July 2005; p. 360.

77. Jamil, I.; Qamarunnisa, S.; Azhar, A.; Shinwari, Z.K.; Ali, S.I.; Qaiser, M.; Jamil, I.; Al, E.T. Subfamilial relationships within Solanaceae as inferred from $a t p$ B-rbcL intergenic spacer. Pak. J. Bot. 2014, 46, 585-590.

78. Jansen, R.K.; Cai, Z.; Raubeson, L.A.; Daniell, H.; de Pamphilis, C.W.; Leebens-Mack, J.; Muller, K.F.; Guisinger-Bellian, M.; Haberle, R.C.; Hansen, A.K.; et al. Analysis of 81 genes from 64 plastomes resolves relationships in angiosperms and identifies genome-scale evolutionary patterns. Proc. Natl. Acad. Sci. USA 2007, 104, 19369-19374. [CrossRef] [PubMed]

79. Olmstead, R.G.; Sweere, J.A.; Spangler, R.E.; Bohs, L.; Palmer, J.D. Phylogeny and provisional classification of the Solanaceae based on chloroplast DNA. In Solanaceae IV: Advances in Biology and Utilization; Nee, M., Symon, D.E., Lester, R.N., Jessop, J.P., Eds.; Royal Botanic Gardens, Kew: Richmond, UK, 1999; pp. 111-137.

80. D'Arcy, W.G. The Solanaceae since 1976, with a review of its biogeography. In Solanaceae III: Taxonomy, Chemistry, Evolution; Hawkes, J.G., Lester, R.N., Nee, M., Estrada, N., Eds.; Royal Botanic Gardens, Kew: Richmond, UK, 1991; pp. 75-138.

81. Symon, D.E. Gondwanan elements of the Solanaceae. In Solanaceae III: Taxonomy, Chemistry, Evolution; Hawkes, J.G., Lester, R.N., Nee, M., Estrada, N., Eds.; Royal Botanical Gardens, Kew: Richmond, UK, 1991; pp. 139-150.

82. Deanna, R.; Smith, S.D.; Särkinen, T.; Chiarini, F. Patterns of chromosomal evolution in the florally diverse Andean clade Iochrominae (Solanaceae). Perspect. Plant. Ecol. Evol. Syst. 2018, 35, 31-43. [CrossRef]

83. Hepper, F.N. Old world Withania (Solanaceae): A taxonomic review and key to the species. In Solanaceae III: Taxonomy, Chemistry, Evolution; Hakes, J.G., Lester, R.N., Nee, M., Estrada, N., Eds.; Royal Botanic Gardens, Kew: Richmond, UK, 1991; pp. 211-228.

84. Hunziker, A.T. Genera Solanacearum: The Genera of Solanaceae Illustrated, Arranged According to a New System; ARG Gantner Verlag: Ruggell, Liechtenstein, 2001.

85. Choi, K.S.; Chung, M.G.; Park, S. The complete chloroplast genome sequences of three veroniceae species (Plantaginaceae): Comparative analysis and highly divergent regions. Front. Plant. Sci. 2016, 7, 1-8. [CrossRef]

86. Abdullah; Waseem, S.; Mirza, B.; Ahmed, I.; Waheed, M.T. Comparative analyses of chloroplast genome in Theobroma cacao and Theobroma grandiflorum. Biologia 2020, 75, 761-771. [CrossRef]

87. Henriquez, C.L.; Abdullah; Ahmed, I.A.; Carlsen, M.M.; Zuluaga, A.; Croat, T.B.; Mckain, M.R. Molecular evolution of chloroplast genomes in Monsteroideae (Araceae). Planta 2020, 251, 72. [CrossRef]

88. Ahmed, I.; Matthews, P.J.; Biggs, P.J.; Naeem, M.; Mclenachan, P.A.; Lockhart, P.J. Identification of chloroplast genome loci suitable for high-resolution phylogeographic studies of Colocasia esculenta (L.) Schott (Araceae) and closely related taxa. Mol. Ecol. Resour. 2013, 13, 929-937. [CrossRef]

89. Dong, W.; Liu, J.; Yu, J.; Wang, L.; Zhou, S. Highly variable chloroplast markers for evaluating plant phylogeny at low taxonomic levels and for DNA barcoding. PLoS ONE 2012, 7, e35071. [CrossRef]

90. Nguyen, V.B.; Park, H.-S.; Lee, S.-C.; Lee, J.; Park, J.Y.; Yang, T.-J. Authentication markers for five major Panax species developed via comparative analysis of complete chloroplast genome sequences. J. Agric. Food Chem. 2017, 65, 6298-6306. [CrossRef]

91. Kimura, M. Model of effectively neutral mutations in which selective constraint is incorporated. Proc. Natl. Acad. Sci. USA 1979, 76, 3440-3444. [CrossRef] [PubMed]

92. Lawrie, D.S.; Messer, P.W.; Hershberg, R.; Petrov, D.A. Strong purifying selection at synonymous sites in $D$. melanogaster. PLoS Genet. 2013, 9, e1003527. [CrossRef] [PubMed]

93. Poczai, P.; Hyvönen, J. The complete chloroplast genome sequence of the CAM epiphyte Spanish moss (Tillandsia usneoides, Bromeliaceae) and its comparative analysis. PLoS ONE 2017, 12, e0187199. [CrossRef] [PubMed] 
94. Mehmood, F.; Abdullah; Ubaid, Z.; Shahzadi, I.; Ahmed, I.; Waheed, M.T.; Poczai, P.; Mirza, B. Plastid genomics of Nicotiana (Solanaceae): Insights into molecular evolution, positive selection and the origin of the maternal genome of Aztec tobacco (Nicotiana rustica). BioRxiv 2020. [CrossRef]

95. Abdullah; Mehmood, F.; Shahzadi, I.; Waseem, S.; Mirza, B.; Ahmed, I.; Waheed, M.T. Chloroplast genome of Hibiscus rosa-sinensis (Malvaceae): Comparative analyses and identification of mutational hotspots. Genomics 2020, 112, 581-591. [CrossRef]

96. Spooner, D.M. DNA barcoding will frequently fail in complicated groups: An example in wild potatotes. Am. J. Bot. 2009, 96, 1177-1189. [CrossRef]

97. Miller, J.T.; Spooner, D.M. Collapse of species boundaries in the wild potato Solanum brevicaule complex (Solanaceae, S. sect. Petota): Molecular data. Plant. Syst. Evol. 1999, 214, 103-130. [CrossRef]

98. Aubriot, X.; Knapp, S.; Syfert, M.M.; Poczai, P.; Buerki, S. Shedding new light on the origin and spread of the brinjal eggplant (Solanum melongena L.) and its wild relatives. Am. J. Bot. 2018, 105, 1175-1187. [CrossRef]

99. Kulcheski, F.R.; Muschner, V.C.; Lorenz-Lemke, A.P.; Stehmann, J.R.; Bonatto, S.L.; Salzano, F.M.; Freitas, L.B. Molecular phylogenetic analysis of Petunia Juss. (Solanaceae). Genetica 2006, 126, 3-14. [CrossRef]

100. Sullivan, J.R. Systematics of the Physalis viscosa complex (Solanaceae). Syst. Bot. 1985, 10, 426-444. [CrossRef]

(C) 2020 by the authors. Licensee MDPI, Basel, Switzerland. This article is an open access article distributed under the terms and conditions of the Creative Commons Attribution (CC BY) license (http://creativecommons.org/licenses/by/4.0/). 